\title{
How does mobility shape parental strategies - a case of the Israeli global middle class and their 'immobile' peers in Tel Aviv
}

\begin{abstract}
We examined the parental strategies of global middle class (GMC) parents currently living in Israel, and compared these to their local middle class (LMC) peers. Both groups of parents were focused on securing advantages for their children through education choices and practices of cultivation. The central difference between these two groups of middle class parents was the ways in which 'mobile-mindedness' was conceived of, and in turn shaped the future aspirations they held for their children. A second critical finding was that this group of GMC actively fostered strong relations to belonging to their 'home' nation, challenging the suggestion of rootless nomads found in the literature. We argue that the GMCs in our sample think locally in each place they settle in order to secure the educational advantage, but act globally with respect to their children's prospective futures. Meanwhile, the LMCs think globally in terms of cultivating forms of capital to secure advantages for their children, but do so with a locally-informed frame of reference for their imagined futures. These conceptual insights into the lived narratives of the GMC have implications for the ways we come to understand this emerging middle class fraction, and should shape further research in this area.
\end{abstract}

Keywords:

Global middle class, parental educational strategies, Tel Aviv, mobility, belonging 
Increasingly, global processes are blurring the geopolitical boundaries between countries and regions, forging closer connections between social and economic systems worldwide (Ball, Dworkin, \& Vryonides, 2010). Beck (2011) has argued that modern civilisation is characterised by a noticeable proliferation of cosmopolitan values, which in turn can threaten forms of national identity, encouraging a view of the world as a single entity. These various economic, social, cultural, and migratory global processes affect people and social structures in across locations and contexts. Globalisation thus operates on an economic-political level as well as fostering new social networks and cultural norms (Chiang, Meng, \& Tian, 2015). International corporations, new media, and inter-personal networks of a global magnitude forge the development of new social structures within 'global cities'. These central cities function as meeting places between people from all over the world (Sassen, 2005), where international connections are created and sustained. Such cities, it is argued, comprise the setting for the emergence of a new social class faction with a unique identity, whose members adhere to a particular set of values and practices; namely, what has been called the 'Global Middle Class' (Ball \& Nikita, 2014).

Although the suggestion that this new social class faction is developing among the middle classes is still (even empirically) contested (Authors, 2018a), the theoretical argument that transnational corporations require a growing service class to facilitate their development is harder to dispute. The global middle class (GMC) mainly refers to a well-educated, economically and culturally resourced segment of the middle class population who have a global orientation, a Western lifestyle, and importantly, extensive experiences of mobility, having lived outside their 'home' countries (Ball \& Nikita, 2014; Burrows, 2015). The mobility of these professionals, many of whom move their families with them as they search for new employment or are required to transfer to other offices of their multi-national corporations, is the critical feature that distinguishes the GMC from their (non-mobile) middle-class peers. As the estimated size of this group has reached 66.2 million and is on track to rise to 87.5 million by 2021 (Finaccord, 2018), the need to study them empirically does too. How might such mobility shape parental strategies regarding education and desired futures for their children? This is the central question of our broader research. While this research question should and could be examined through a variety of approaches and prisms, we have decided to focus on a comparison between a globally mobile group of parents and their middle class peers living in one city, who apart from previous and anticipated mobility by the former group share many other characteristics. To date we have empirically examined another group of Israeli GMCs those currently living in London (Authors, 2018) and compared the parenting experiences of Israeli GMCs and Israeli upper middle class migrants, where the latter have decided to relocate 
permanently once only for work or political reasons (Authors, 2019). The latter focus allows us to compare two quite different forms of relocation mobility. Meanwhile, in this paper, we compare a group of Israeli globally mobile middle class professionals currently living in the city of Tel Aviv, Israel, with a sample of Israeli local upper middle class (LMC) professionals permanently residing in the same city. The purpose of this comparison is to elicit whether the former group's experiences of mobility appears to affect their parenting and educational strategies and more broadly to ascertain whether GMCs can be thought of as a distinct faction of the upper middle class, shaped by and through their extensive mobility experiences. This comparison is important in the sense that it allows us to delve into the specific manifestations of constant mobility, and the varied impacts on parental strategies, of a group of parents with otherwise very similar characteristics

Despite being a conflict-ridden and immigrant society, Israel maintains a globally competitive economy (Authors, 2015). A study by the Taub Center (published by Lahav, 2014) has categorised the Israeli middle class into two groupings based on their occupation and income levels; $40 \%$ of Israeli citizens belong to the lower middle class and $29 \%$ of the population belongs to the upper middle class. Many Israelis in the upper middle class are involved in the high-tech, law, and academic sectors and live in the Tel Aviv area (Bar, 2010). The present study focuses on this upper middle class group, specifically addressing whether and how orientations to mobility might create important differentiations between members of this same social stratum.

Thus, to ensure that we have isolated mobility as a key differentiating factor between these upper middle class groups, we limited our sampling approach for GMC participants to those who were Israeli Jewish families who currently live in the Tel Aviv metropolis, are involved in work roles that require them to interact with other professionals at a global level, have frequent experiences of short-term mobility for work, have lived abroad with their children for at least one year. The LMC were recruited among families residing in the same area, working in local occupations (See Table 1 for details). The qualitative study is based on in-depth, semi-structured interviews, conducted by the third author. The interviews were based around discussions on three key issues we anticipated as being relevant to one or both of our groups - GMC and LMC - based on previous research: strategies for success (central in studies of middle class parenting), belonging (the literature suggests that GMCs lose the usual anchors through which to form relations of belonging due to their constant mobility); and mobility and its meanings (a broad concept that can take many forms, as well as being a potentially distinguishing feature between the two groups).. 


\section{Strategies for success}

There is a relatively large body of scholarly work highlighting the 'concerted cultivation' strategies which middle class parents all over the world engage in (Lareau, 2003; van Zanten, 2009; Nogueira, 2010; Reay et al., 2011; Vincent et al., 2012; Irwin \& Elley, 2011; Rowe, 2017; Roch et al., 2018). Whether directly drawing on a Bourdieusian framework or not, middle class parents are argued to be ambitious in seeking to secure and extend their children's advantages, expose their sons and daughters to a broad range of extra-curricular opportunities, help them to identify their talents, but also develop them as a whole rounded person (Stefansen \& Aarseth, 2011; Authors, 2016). As van Zanten (2016) argues, middle class parents can draw on their own knowledge and personal but also professional experience of how to manoeuvre through systems of education to their children's advantage - conceptualised as a form of cultural capital. Critically, it is also the economic resources that are available to middle class families that facilitate strategies of concerted cultivation - paid extra-curricular activities, private academic tutoring, (usually) mothers able to work part-time or become a full-time stayat-home-parent, trips abroad for leisure but also language tuition and so forth (van Zanten, 2015; Authors, 2016).

A central question is how might being constantly globally mobile affect the kinds of middle class parenting and education strategies detailed above, if at all. As Breidenstein et al. (2018) demonstrated in their study of globally mobile professionals interacting on a website discussion fora about school choices in Berlin - some parents want to replicate what they know in a new space, while others want to embrace new opportunities that mobility affords them and their children. Authors (2018b) show in their study of global middle class families in London that while parental aspirations are being negotiated within a global frame of reference in terms of future employment and anticipated mobility of their children, while also significant resources are invested to securing the best opportunities for their children in their contemporary locations (area of residence, school chosen, friendship networks promoted, extra-curricular activities engaged in, keeping in touch with family and other developments 'back home'). Knowledge of the local system they have entered is accumulated through networks and connections. This raises the critical issue, highlighted by Lareau et al. (2016), that in order to make 'choices' or draw on the necessary capitals to shape practices to their advantage, parents need to understand 'the rules of the game', as Bourdieu (1984) would argue. While Lareau et al. (2016)'s study is actually focused on a non-mobile population in one part of the US seeking to gain access to particular early years institutions, their argument is even more critical for mobile families as they settle into a new cultural and organisational space. How, therefore, do GMC parents decide upon entering a new education systems how best to successfully 
manoeuvre their way through? Do these mobile parents focus on other strategies of cultivation, that substitute or augment educational choices, that are different to their local middle class peers? These are not questions which have been studied before.

\section{A sense of belonging}

It has been argued that mobility shapes desires for the future and relations families have to the 'home' nation, the formation of social networks, and the seeking out of a sense of belonging for their children (Favell, 2008). It can be useful to consider the 'frames of reference' (Savage et al., 2005) parents draw on when determining the above - are they local (in which case local to the geographic space in which they are currently residing, or to their home nation), or more global in scope? A global frame of reference invites the suggestion of a cosmopolitan or global citizenship orientation (Authors, 2016; 2017), of acceptance, intrigue and comfort with engaging with the 'Other' but also potentially about being the 'Other' in a particular context. In such situations, elective forms of belonging (Savage et al., 2005) might be more likely to emerge, where the meaning of place is relationally constituted to both a physical, social and imaginary space, that best meets families' needs and desires.

Some theoretical writing on the GMC argues that the state of being constantly mobile leads to a 'rootless' existence, the emergence of 'third culture kids' and a sense of being global citizens (Pollock et al., 2009). Some newer empirical work (Authors, 2018), meanwhile, showed that such forms of persistent mobility might be closely connected to the retention of sustainable ties with the ones' home nation. We posit that the state of having been mobile and anticipation of being mobile again in the future, is critical in shaping parenting practices and future aspirations, which in turn shape the kinds of educational strategies engaged in, and the sense of belonging they aim to develop in their children. The article therefore seeks to understand how GMC and LMC families' sense of belonging may be more locally or globally determined and whether and how experiences of physical mobility shapes this.

\section{Mobilities}

One of the most distinguishing features of the GMC is their pervasive mobility - physical and virtual. Here virtual mobility refers to the use of innovative communication technologies for maintaining professional and social relations (Storme et al., 2017). Mobility means moving to live in one or more places outside their 'home' country, having to travel regularly for work and liaise with professionals based across the world, while also having social and family networks that are maintained virtually and through travelling to see them. In this study we have focused on how these intensified forms of mobilities (Urry, 2007) can be understood as potentially distinguishing GMC from LMC in terms of their parental and educational strategies. As Favell 
(2008) found in his study of young professionals moving across Europe for work, mobility was articulated as 'liberating' them from some of the national social and cultural structures they perceived as oppressive back 'home'. Although Andreotti et al. (2015) found that relationships to home might shift when these professionals had to take into account the needs of children (and spouses), empirically we do not yet know enough about how the act of being mobile for work, the experiential aspect of learning to settle in a new space, and the expectation of continued mobility may alter GMCs' orientations to 'home'. Furthermore, we need to understand how mobility itself might shape approaches to education - in the present and future - as well as more broadly the GMC's ambitions for their own and their children's professional and personal futures. This is a central element to consider - how mobility shapes future ambitions and education choices practised by middle class parents. 


\section{Methods}

\section{Sample}

The study focused on ten families (where both parents were interviewed): five GMC families and five MC families. Each of the parents was interviewed separately, often on different days, due to the parents' schedule. We chose parents who met our criteria of mobility and socioeconomic class group, and who had at least one school-age child. The participants were recruited through the personal connections of the third author, who worked as a private tutor for primary school children in one of Tel Aviv's most affluent neighbourhoods - and also the area where recruited families (GMCs and LMCs) resided.

In the LMC group, parents chosen to be interviewed worked in local professional occupations such as law and the civil service, and where their work did not require them to travel routinely or relocate abroad. In the GMC group, we interviewed parents who were active in distinctively globally-oriented professional fields such as the hi-tech and technology industries. To be included in this sub-sample, families had to have lived abroad, for at least one year (See table 1). These families had friends who lived abroad, regularly communicated with colleagues based in several different countries and travelled abroad often (see Tables 2 and 3 for details). There were two families, who following the interview, did not fully met these criteria, and their data was completely omitted from the analysis. For instance, criteria for exclusion included being mobile, but working in a local organisation which mainly engages with the Israeli market; or a family where only one parent had relocated for work with only one of the children. To make up for their omission from the study, two further GMC families were recruited. Thus, our two groups had similar educational backgrounds and current socioeconomic positions, lived in the same residential area, and had similar family characteristics such as being married, having children at school age and so forth. The only critical difference was the persistent mobility required of the parents as part of their everyday work lives (in the past, present and future).

\section{Data collection and analysis}

The study was based on a qualitative approach, whereby semi-structured, in-depth interviews were conducted and then thematically analysed (Bauer \& Gaskell, 2011). Our inquiry focused on schooling choice, extra-curricular and leisure activities, the parents' perceptions of and wishes regarding their children's imagined futures. We interpreted the statements constructed through the interview process through the constant comparison method, moving between the GMC and LMC families and within the groups. 
The purpose of the study was not to attempt to reconstruct a true reality, but rather to expose the perceptions of reality and the personal stories of participants (Bauer \& Gaskell, 2011; Josselson, 2013). Data interpretation aimed to analyse the phenomenon Ethical clearance was secured through the University Ethics Committee. All names in the text were replaced with pseudonyms.

There are several limitations to this study, which we outline here. In our view, these do not undermine the contribution made to the field. First, as the study follows a very specific group of parents in terms of nationality and religion, the question of generalisation arises. We are aware of the uniqueness of our sample (Israelis living in their home nation), but we also argue there is value gained in exploring the broader questions related to the GMC by focusing on one nationality in one location, thus eliminating biases related to a more heterogeneous sample. This particular focus is a means to empirically examine key ideas from the literature and develop more nuanced theoretical ideas which can then be applied to other groups and locations in future research. A second limitation is arguably our focus on one residential neighbourhood of Tel Aviv. We nevertheless suggest that a tightly-focused sample against reduces the degree to which heterogeneity might affect the development of the theoretical constructs we are seeking to offer.

\section{Findings}

We present below the main themes of our analysis, comparing the GMC and LMC informants' practices and perceptions of education, mobile futures and belonging. In doing so, we relate these back to the three concepts presented in the theoretical background. We consider how parental aspirations for their children are narrated by our interviewees and how they articulate a sense of belonging - which was revealed as key to shaping parenting strategies and imagined futures for their children.

\section{Educating for success}

We found important similarities across the GMC and LMC families in terms of their articulated values and identified educational strategies employed in relation to their children. All informants expressed a clear intent to equip their children with the necessary self-confidence and self-efficacy through family practices and education choices and thus to preserve their advantage in the field (Reay et al., 2011; Vincent et al., 2012). Participants emphasised the need for their children to pursue success and demand high attainment for themselves. All families articulated a self-awareness of their role in facilitating their children's pathways into 
successful and fulfilling futures and engaged in proactive practices of enculturation.

In most cases, both groups engaged in strategic decision-making in relation to the school chosen for their children. Parents sought to make sense of the local environment and how this might affect schooling offers, approaching decision-making in a seemingly rationale manner. Sometimes, parents would move to particular neighbourhoods where they aligned higher socioeconomic status with higher quality schooling. Both GMC and LMC parents focused on how the local environment was linked to the type of student body found in a school, and indirectly associated higher socio-economic status with schools where the culture appropriately fostered academic attainment and ambition.

Ben (LMC father): "The type of people [in a neighbourhood] ultimately affects the people that reach the school. The people that come to school influence the level of education, the atmosphere in the school, the level of violence, and the values that the children assimilate. Parents impart values beyond what is needed, or things that need to go beyond the curriculum. It all depends on the people, on the values the people give their children and what they bring with them to school."

Max (GMC father): "I think it's a combination between the type of people, the type of parents, and the involvement of the parents."

Oscar (LMC father): "It's important to me that he [his son] will be with a good cohort, not a regular cohort, with a slightly more well-resourced ... in terms of culture. I prefer that my children won't be with inferior people... I personally can manage anywhere. If I'm working in south Tel Aviv, or living in north Tel Aviv with all the V.I.P, I can still manage. I've already been through a lot in life, but for them [his children], it's important to be with a good people."

Rachel (GMC mother): "I would like my child to learn with people as similar as possible, with parents who will be as similar to us as possible on a socioeconomic level, with similar values of excellence and respect, rather than mediocrity. Yes, it's very important to me."

Marcus (LMC father): "If I look around at school and I see an inferior people, then my children won't be enrolled in this school. It is not only the people, it's also the level of education in the school, to be precise."

Similar narratives were constructed when GMC parents discussed school choice-making while living abroad. These parents tended to favour selective and/or private schooling, viewing these as markers of excellence but also as ensuring the 'right' kind of demographic 
cohort for their children to be educated alongside. In order to try and make the right decision, they consulted education agents linked to their corporations who supported the relocation process, local contacts they had, or other publicly available information on the characteristics of various residential neighbourhoods they could move into.

Experiencing the world featured highly in the kinds of family activities described by the participants. Holidaying abroad has increased among many families in Israel in recent years (Blumen, 2015), and the parents interviewed considered such activities to be both for pleasure but also necessarily educational.

Rachel (GMC mother): "My kids were in the US a few times, they were in Europe, Alaska, in Asia, Vietnam, they were in many both classic and exotic places and they travelled a lot, it is important to be open to the world."

Betty (LMC mother): "We make sure to travel with them [the children] from a very young age, going on trips abroad, and of course within Israel as well. In Israel we go off on a regular basis, but also at least once a year we go abroad as well. The last trip was a trip to the Far East, to the third world, to Vietnam and Thailand, because I think it's very important, and even if they do not remember anything (and my little ones will not for sure) it teaches them that the world is big and there are many kinds of people, many ways to live a life. Some people look different, and make you feel different, that you are suddenly in a different place, I think that is important to the child."

For all the parents interviewed opening their children's eyes to scale, range, and difference through travel was critical, as part of an attempt to develop a more cosmopolitan attitude, an ease with mobility and perhaps broadening out their frames of reference when making sense of their own experiences and lives. Critical in promoting a more cosmopolitan orientation, but also preparedness for mobility was the need to develop a competent standard of English, given its importance within the education, academic and business spheres within Israel and beyond (Shohamy, 2014). Most families were paying for private tuition and extracurricular activities (see Tables 2 and 3 for details).

Ella (LMC mother): "I am very strict on them with the English private tutoring, both of them regularly attend [private lessons]...I see how important it is nowadays, and here at the neighbourhood there are many kids who have a very high level of English..." 
Betty (LMC mother): “We're moving towards becoming a global village, and whoever doesn't speak its language can't integrate into it, and because I believe that that's the future, it's perhaps the most important school subject for my children."

Here, though, the intensity and approach to facilitating an ease with this global language highlighted some differences between the two groups - GMC and LMC. While participants in both groups had a certain level of English proficiency due to being graduates of the higher education system in Israel or elsewhere, those in the LMC group tended to feel that learning English in school and occasionally hiring a tutor was sufficient. Meanwhile, GMC parents, such as Tom, took a more active role in imparting the necessary language skills to their children, taking care to also address the nuances of accent and promoting a confidence in the language as an asset that makes the difference.

Tom (GMC father): "If I can speak English to them and transmit the language to them that way, I see no reason not to. I actually know parents whose mother tongue is not Hebrew, and they don't bother speaking their language to their children. I think it's a crime. The child has the capacity to absorb a second language almost effortlessly. You don't even have to set aside time for it, you don't have to declare it as a goal. You don't have to send him to language classes or hire a tutor. You just speak it every day and transmit it to him."

Meanwhile, when Betty (LMC) was asked whether she spoke to her children in a language other than Hebrew, she replied:

"Yes, well, unfortunately phrases in English can fly in, involuntarily ...I hate when you're saying something, and out comes some English expression or word, it's like...it happens a lot...[but] it's fake...it's not my language."

In contrast, GMC parents intentionally implemented a multilingual dialogue strategy as an integral part of their family practices. They viewed such an approach as natural and logical, as a way to foster their children's potential and provide them with social and academic advantages (Song, 2010). For the GMC families talking in English at home was feasible because of their own significant language capacities gained through communicating daily in English for work, and having lived abroad where English was often used as the main mode of interaction.

Based on our interviews it would appear as if members of the LMC and GMC share very similar interests, pursue the same leisure activities, and regularly vacation abroad. Indeed, both groups of parents seek to remain 'one step ahead' (Reay et al., 2007; Vincent et al., 2012) by engaging 
in concerted cultivation practices that will facilitate a future trajectory that is 'successful' in their view - higher education, a professional career, a comfortable income. For these parents it is important that their children be ambitious for themselves.

Rachel (GMC mother): "From our point of view, mediocrity is not something that is considered; therefore, they [the kids] are on these [academic] tracks."

Ben (LMC father): "The values of a desire to succeed, and ambition are important to me. Ultimately, we are here to enjoy ourselves and also to try to influence everything that happens as much as we can.”

Our findings therefore concur largely with the broader literature on middle-class education strategies. The participants are largely unapologetic about their strategising to ensure their children are advantaged through schooling and extra-curricular opportunities, and we found similar responses among both LMC and GMC families.

\section{Belonging - remaining rooted despite persistent mobility}

The scholarship on the GMC suggests that their constant mobility alters their class identities and promotes a form of cosmopolitan citizenship, no longer rooted to a particular nation-state (Ball \& Nikita, 2014; Beck, 2011). Thus, their relationships to the concept of 'home' becomes very fluid, as they maintain multifarious ties to their countries of origin, their new countries of residence, and their variously-located professional and social networks (Ball \& Nikita, 2014). Our study therefore sought to examine how our GMC participants conceived their sense of belonging. We found that our Israeli GMC parents saw the Land of Israel and its relevance to Jewish identity very similarly to that expressed by the LMC families. Thus, all parents in our study seek to impart to their children a love for their country of origin, the Jewish faith, Jewish cultural traditions, and the Hebrew language. In response to the question exploring the kinds of values parents seek to instil in their children, Ella (LMC mother) explained:

"Love of Israel...obviously they're going to serve in the Israel Defence Forces. No question about it."

Ellen (GMC mother): "So just an anecdote...they know exactly what is expected from them, excel in the school, army is a MUST ('a must' was said in English), then university. So, the youngest he is only ten and he told us the other day that he would like to do the after-army trip to three countries and I said, 'OK sure, first get an offer from the university and then you can go'... and just think of that - he is only ten and he was like 
'of course' and I said 'yep, just wanted to make sure"'.

Ellen (GMC mother): "They know that we have an army, and it must exist, and they also know that after serving, they'll attend university. That's clear. We have to protect our territory. We're not here randomly, and we can't depend upon anyone else. Surrounding us are more than a few threats; we're not blind to this. I fervently hope there won't be war, but yes, in defence terms, I'm Zionist at heart. We read a lot in our home about Israel's heroes and historical leaders, and the Zionist agenda that led to the establishment of the state, and I tell him [her son] that it's our privilege to know that you too can do your part for the state, and that each of us [she herself and the father] did so [served in the army]."

The Israeli GMC emphasised their sense of belonging to Israel and to the Jewish people. They also sought to conceptualise their continuous mobility around the world as a form of relocation for employment purposes rather than an act of emigration. This perception of migration as temporary, with the ultimate goal of returning to live in Israel is not unique to the constantly mobile GMC families, but has been identified through previous research on Israeli migrant communities around the world (Gold \& Hart, 2013). Due to the Zionist project of Israel, for many emigration is strongly frowned upon. The GMC parents in our study identified themselves first and foremost as Jews and Israeli, who have the capacity to move to other parts of the world when needed, but who still felt a strong connection to their homeland.

Tom (GMC father): "I don't think there's a contradiction [between Zionism, mobility, and relocation]. You can be Zionist and reside abroad for a few years. It's possible that doing so even strengthens your Zionism, and you can help others in your community where you reside abroad in terms of [their connection to] the Land of Israel. I don't think there's a contradiction there. Right now we're here, and our twins are serving in the IDF [Israeli Defence Force], and I imagine that our younger sons will too, with all the education and Israeli-Zionist values that that entails."

Even when Israeli GMC parents lived abroad, they actively cultivated a sense of belonging to Israel:

Alexander (GMC father): "When we were residing in Boston [we enrolled them in] a private school, a Jewish one by the way, for a clear reason - the issue of being Jewish abroad, and particularly Israeli in a foreign country, and knowing that it's just temporary - it was very, very important to us to retain the environment of Judaism while in Boston." 
Lisa (GMC mother): "We always stayed connected. For example all our vacations while living in various places abroad were in Israel"

Ellen (GMC mother): "We chose the Jewish environment there (in the US), to give them some sense of roots. There are always on move with new language, new environment, so we wanted them to have at least that...to lean on that"

Kim (GMC mother): "We basically insisted that they attend those Jewish lessons, because we wanted their base to be strong. It is true that I am not anticipating them to live in Israel all their life, but still...I don't know...I want them to have the same experiences that I had as a child in Israel"

Indeed, the data suggests that the GMC tended to, while relocating abroad, mostly choose Jewish schools and extracurricular activities that incorporated the learning of Hebrew, as a way of consolidating their children's Jewish heritage, and a Zionist commitment to Israel. Ideally, for the GMC parents interviewed, they would be able to combine this with the best school choice available locally.

Tom (GMC father): “Again, Jewish education, Jewish values, and high quality education. Their scholastic performance, the kids graduating from there come out with the best skills. [In the US] I asked the principal before the boys enrolled what their college admissions rate is, and he told me he didn't remember the last time that one of his pupils didn't get accepted to a college, he said ' $100 \%$.' That's quality. And many of them go to Ivy League schools."

Lee (GMC mother): "So in the US we also did the same as in Switzerland with choosing schools for them. We asked people, there are lists and we wanted a good school. There when you go for the Jewish school, it is already of the better schools. So that is how we chose"."

The GMC families in our sample therefore sought to shore up their children's sense of belonging to Israel while living abroad, but many in fact suggested that their mobility actually necessitated they focus more concertedly on ensuring this, perhaps leading their children to have an even stronger sense of commitment to the country and the broader project that Israel represented. Alexander (GMC father) explained:

"Like I said, this is a global world and I really want the world to be open for them. They have all the things (values) from here, with hiking every week and knowing 
Israel and then they do the same in other places. You need this to have the world open to you (in Hebrew 'under your legs')".

Thus, from our data we suggest that the GMC and LMC Israeli parents held very similar views as to what it means to 'belong', with the promotion and embedding of an Israeli/Jewish identity playing a large role in shaping their educational practices - both in Israel and abroad. Moreover, the narratives of the GMC parents suggested that their cultivation of a sense of belonging could be viewed as a particular articulation of a form of cultural capital. That is, resources are being accumulated through family educational strategies (celebrating Jewish holidays, cultivating a love of Israel etc.,) which are then drawn on to strengthen the children' psychological / psychic base which in turn sustain them during future episodes of mobility (Authors, 2018). Thus, as the parents suggested, this resource or sense of surety about belonging might not only help to mitigate the effects of their constant movement around the globe, but also, as Alexander suggests above, promote future opportunities in terms of education and employment (seeking opportunities on a global stage) and maintaining a sense of ease with being mobile (by hiking in Israel and learning that the feel of the land is the same wherever they might go).

\section{Imagining the future - at what scale?}

Our research suggests very strong similarities between the GMC and LMC groups studied in terms of their cultivation strategies to educate successful, cosmopolitan, rounded children, as well as a jointly-held commitment to developing a strong sense of belonging to the Land of Israel. However, when parents articulated their desires for the kinds of futures their children might inhabit, a clear effect of their own experiences of physical and virtual mobility emerges. GMC, unlike LMC, parents view their children's futures as unfolding on a world stage. Opportunities can be pursued anywhere across the globe, re-locating is normalised, and success seen as assured.

Tom (GMC father): "One of my sons wants to attend the Technion [Israeli Institute of Technology], and I hope that he gets in. My other son wants to attend Oxford. I hope he fulfils his dream too. Each one has his own aspirations. The important thing is that it be a good university, that the education there is good, that it prepares them. It doesn't matter where, or in which country... I want them to make a good living, so they reach the tops of their professions, in whatever career they choose, anywhere, and get the most out of their careers."

Rachel (GMC mother): "For intelligent people, we need to open up as many 
possibilities as possible to information, curiosity, personal development, to change... [my children should attend] the world-renowned universities such as Harvard, Yale, Princeton, Stanford, Cambridge, Oxford, places they deserve and places that lead people to success - it's a superior value for me."

The confidence emanating from these narratives belies a sense of surety about successful futures found in work on elite education elsewhere (Authors, 2013, 2018b; Forbes \& Lingard, 2015). These parents seem to believe that the concerted cultivation of their children, while requiring work, will bear fruit, a similar discursive trope found in other studies of the middle class parents. Despite this similarity, the GMC parents are nevertheless different from the LMCs, specifically in the global nature of their future desires for themselves and their children. The preparedness to successfully secure their place in the world, starts immediately after they were born according to Patrick (GMC father):

"From the day they were born, it was important to us that they make their way in the world, even in terms of the names we named them: We gave them names that are easy to type, and easy for foreigners to pronounce, but also Israeli names that are understood universally, that don't sound strange or have letters that foreigners can't pronounce. Another thing we did from Day One was to speak to them in English. Not connected to relocation; it was just important to us that they have a second language at mother-tongue level (our emphasis)."

Meanwhile, the narratives created by the LMC parents in our sample differed slightly in terms of the assuredness woven in them, and they were specifically locally-oriented in terms of future aspirations - within Israel's borders.

Sharon (LMC mother): “Today, if you are not educated, didn't study at a university (with reference to Israeli universities), you cannot go anywhere; and yes, it is important to learn and to succeed."

Oscar (LMC father): "I can tell you that its very, very important to me, I will support them financially, so they will go and learn as much as possible... I'm talking with them about this... From this age I teach them that a child should be educated, invest in studies already. If he does not invest from such age, he will not be accepted to the (Israeli) university.”

Betty (LMC mother): "I want them (the kids) to know that they will grow up and live here and their children and their grandchildren" 
Striking in the comparison between our two groups of participants was how the experiences of mobility so strongly differentiated the boundaries shaping the futures they desire and expect for their children. While perhaps obvious, given the GMC parents' mobility for work, this point is critical as we consider the spatiality of processes of reproduction and the potential formation of new cadres of global and elite workers driving process of economic productivity. The GMC appeared to draw on a global frame of reference when imagining future possibilities. Given their practices of mobility had been facilitated with ease due to the needs of their employers, they seemed confident the same opportunities would be readily available to their children - facilitated by access to elite higher education institutions, experiences of travel and mastery of the English language. Thus, although the GMC and MC families have to engage in strategic choice-making within a local field - be it in Tel Aviv or when living abroad, such localised practices are actually seeking to make possible quite different futures - and this is key as we seek to empirically establish whether a new fraction of the middle classes is being formed. Critically, however, the GMC parents in our study draw on a very rooted sense of belonging and actively cultivate this wherever they are living, partly we suggest as a mechanism for developing this sense of surety about the self, one's identity and the kinds of values that should be driving their practices.

\section{Conclusion}

This study starts to make the necessary empirical contributions required to facilitate the further development of conceptualisations of the GMC - drawing on data to examine how this emerging social group fraction may or may not be different to their more locally emplaced LMC peers. Through our comparative analysis of Israeli GMC educational strategies, we highlight two significant characteristics shaping these families' practices - a naturalisation of an expectation of mobility in their and their children's future lives, but also a concerted cultivation of a sense of belonging to their 'home' nation. Moreover, when comparing the GMC's narratives to those of their non-mobile counterparts we can see the various and different ways they draw on local and global frames of references when discussing their parental strategies.

In fact, the educational strategies of both the GMC and LMC parents in this study could be articulated through the aphorism, "think globally, act locally." The LMC families engage with the global by cultivating skills and orientations that acknowledge the impact of globalisation on the world of work, politics, travel, and social networks. However, these practices (developing self-confidence, self-efficacy, proficiency in English, environmental 
awareness, and physical activity) are aimed at securing their children's place within the local field of power (i.e., in Israeli society). Meanwhile, the GMC parents we interviewed also practice education locally by competing to secure the best opportunities and services for their children wherever they are currently located; but they do this to pave the way for an imagined future that transcends Israel, and finds their children leading successful lives anywhere in the world.

The persistent mobility that characterises the lives of GMC individuals provides them and their families not only with additional tangible resources, skills, and experiences (such as higher levels of English proficiency and certain intercultural sensitivities), but it also facilitates the formation of a form of existence and consequently an approach to parenting which could be understood as a form of 'mobile-mindedness', which is incorporated intensively into their parental conceptions and priorities. 'Mobile mindednesses' thus can be seen as a set of dispositions and practices employed by constantly mobile families to sustain their advantage in an ever-changing educational and social landscape as they move from place to place. Nevertheless, in the specific case of the Israeli GMC, their persistent mobility leads neither to rootlessness nor to a looser sense of belonging for such families. On the contrary, they employ proactive cultivation strategies to reinforce their children's connection to their Israeli identity and heritage, utilising this sense of belonging as an additional asset, or capital that allows and facilitates continued and constant mobility into the future.

Mobile-mindedness, as shown here, might serve as a useful concept for further research on this emerging class faction, as they are required to psychically and practically negotiate constant motion in time and space, while needing to find the resources necessary to facilitate a sense of identity. Such a concept is, we argue, linked to Savage at al.'s (2005) notion of 'elective belonging' - as relations to physical, social and imaginary space inform understandings of belonging. Our research suggests that mobility does not in fact drive families to become more or less rootless. Our participant narratives emphasise that GMC families see themselves as global citizens who come from, and should always be able to return to, 'somewhere' (in their case Israel), however temporarily. This sense of belonging will shape the practices they engage in in the new communities they relocate to and arguably drive a strategically cultivated sense of belonging. In the case of the Israeli GMC families - forging connections to other Jewish peoples and local Jewish organisations appeared paramount. Extending such an analysis might suggest such families engage in very elective and segregated relations of belonging and therefore do not seek to exploit the potential for multicultural relations of affinity global cities arguably make available (Sassen, 2005; Authors, 2018). This challenges the construct of GMCs offered to date by the largely theoretically-developed 
Miri Yemini, Claire Maxwell \& Ma'ayan Mizrachi (2018): How does mobility shape parental strategies - a case of the Israeli global middle class and their 'immobile' peers in Tel Aviv, Globalisation, Societies and Education, online 1 October 2018.

literature. 


\section{References}

Authors $(2013 ; 2015 ; 2016 ; 2017 ; 2018 ; a ; b ; 2019)$.

Andreotti A, Galès PL and Moreno-Fuentes FJ. (2015) Globalised minds, roots in the city: Urban upper-middle classes in Europe. Chichester: John Wiley \& Sons.

Ball, S. J., Dworkin, A. G., \& Vryonides, M. (2010). Globalization and education: Introduction. Current Sociology, 58(4), 523- 529.

Ball, S. J., \& Nikita, D. P. (2014). The global middle class and school choice: a cosmopolitan sociology. Zeitschrift für Erziehungswissenschaft, 17(3), 81-93.

Bar, A. (2010). The characteristics of the middle class in Israel and an analysis of the changes that have taken place in recent years. Jerusalem: The Knesset Research and Information Center. Retrieved from https://www.knesset.gov.il/mmm/data/pdf/m02671.pdf (Hebrew).

Bauer, M., \& Gaskell, G. (2011). Qualitative Research: Methods for analyzing text, image and sound. Ra'anana: The Open University. (Hebrew).

Beck, A. (2011). Cosmopolitanism: Critical theory for the 21st century. Tel Aviv: Hakibbutz Hameuchad. (Hebrew).

Blumen, O. (2015). Employee benefits and high-tech fatherhood. Journal of Managerial Psychology, 30(5), 535-549.

Bourdieu, P. (1984). Distinction. London: Routledge \& Kegan Paul.

Breidenstein, G., Forsey, M., Gro, F.L., et al. (2018). Choosing international: a case study of globally mobile parents. In: C. Maxwell, U. Deppe. H-H. Krüger et al. (Eds.), Elite education and internationalisation (pp. 161-179). Basingstoke: Palgrave Macmillan.

Burrows, M. (2015). The emerging global middle class-So What? The Washington Quarterly, 38(1), 7-22.

Chiang, T. H., Meng, F. H., \& Tian, X. M. (2015). Globalization and elite universities in China. In A. V. Zanten., S. J. Ball., \& B. D. Koechlin (Eds.), World yearbook of education 2015: Elites, privilege and excellence: The national and global redefinition of educational advantage (pp. 111- 126). Abington, Oxon \& New York, NY. Routledge.

Favell, A. (2008). Eurostars and Eurocities: Free movement and mobility in an integrating Europe. Oxford: Wiley-Blackwell.

Finaccord, (2018). Global Expatriates: Size, segmentation and forecast for the worldwide market. London: Finaccord. Retrieved from http://finaccord.com/uk/report_globalexpatriates_size-segmentation-and-forecast-for-the-worldwide-market.htm

Forbes, J., \& Lingard, B. (2015). Assured optimism in a Scottish girls' school: habitus and the (re)production of global privilege. British Journal of Sociology of Education 36, $116-$ 136.

Irwin, S., \& Elley, S. (2011). Concerted cultivation? Parenting values, education and class diversity. Sociology, 45(3), 480-495. 
Gold, S., \& Hart, R. (2013). Transnational ties during a time of crisis: Israeli emigration, 2000 to 2004. International Migration, 51(3), 194-216.

Josselson, R. (2013). Interviewing for qualitative inquiry: A relational approach. New York, NY: Guilford Press.

Lahav, L. (2014, May 23). Research: There is a middle class and there is a middle class. Yedioth Ahronoth Y-net. Retrieved from http://www.ynet.co.il/articles/0,7340,L4521857,00.html (Hebrew).

Lareau, A. (2003). Unequal childhoods. Berkley: University of California Press.

Lareau, A, Evans, S.A., \& Yee, A. (2016). The rules of the game and the uncertain transmission of advantage: Middle-class parents' search for an urban kindergarten. Sociology of Education 89, 279-299.

Nogueira, M.A. (2010). A revisited theme - middle classes and the school. In: M. Apple, S. Ball \& L. Gandin (Eds.), The Routledge International Handbook of the Sociology of Education (pp 253-263), Abingdon: Routledge.

Reay, D. Crozier, G., \& James, D. (2011). White middle class identities and urban schooling, Basingstoke: Palgrave Macmillan.

Roch, A., Dean, I., \& Breidenstein G. (2018) Between 'enrichment' and 'endangerment': 'cultural diversity' and the politics of belonging in the Berlin school choice discourse. Ethnography and Education 13,137-153.

Rowe, E. (2015). Theorising geo-identity and David Harvey's space: school choices of the geographically bound middle-class. Critical Studies in Education 56, 285-300.

Sabar Ben Yehoshua, N. (Ed.). (2001). Traditions and trends in qualitative research. Tel Aviv: Dvir. (Hebrew).

Sassen, S. (2005). The global city: introducing a concept. The Brown Journal of World Affairs, $11(2), 27-43$.

Savage, M., Bagnall, G., \& Longhurst, B. (2005). Globalization and belonging. London: Sage Publications Ltd.

Savage, M., Hanquinet, L., Cunningham, N., \& Hjellbrekke, J. (2018). Emerging cultural capital in the city: profiling London and Brussels. International Journal of Urban and Regional Research, 42(1), 138-149.

Shohamy, E. (2014). The weight of English in global perspective. Review of Research in Education, 38(1), 273-289.

Song, J. (2010). Language ideology and identity in transnational space: Globalization, migration, and bilingualism among Korean families in the USA. International Journal of Bilingual Education and Bilingualism, 13(1), 23-42.

Stefansen, K., \& Aarseth, H. (2011). Enriching intimacy: the role of the emotional in the 'resourcing' of middle class children. British Journal of Sociology of Education, 32(3), 389-405. 
Storme, T., Faulconbridge, J. R., Beaverstock, J. V., Derudder, B., \& Witlox, F. (2017). Mobility and professional networks in academia: An exploration of the obligations of presence. Mobilities, 12(3), 405-424.

Urry, J. (2007) Mobilities. Cambridge: Polity.

van Zanten, A. (2009). A Choisir son école. Stratégies parentales et médiations locales, Paris: Presses Universitaires de France.

van Zanten, A. (2015). A family affair: Reproducing elite positions and preserving the ideals of meritocratic competition and youth autonomy In: A. van Zanten, S. Ball, \& B. Darchy-Koechlin (Eds.), Elites, privilege and excellence: The national and global redefinition of educational advantage (pp. 29-42). London: Routledge.

van Zanten, A. (2016). Promoting equality and reproducing privilege in elite educational tracks in France. In: C. Maxwell \& P. Aggleton P (Eds.), Elite education. International perspectives (pp. 114-125). Abingdon: Routledge.

Vincent, C., Rollock, N., Ball, S., et al. (2012). Being strategic, being watchful, being determined: Black middle-class parents and schooling. British Journal of Sociology of Education 33, 337-354. 
Miri Yemini, Claire Maxwell \& Ma'ayan Mizrachi (2018): How does mobility shape parental strategies - a case of the Israeli global middle class and their 'immobile' peers in Tel Aviv, Globalisation, Societies and Education, online 1 October 2018.

Table 1: Inclusion criteria/characteristics of GMC versus the LMC parents in this study

\begin{tabular}{lll}
\hline & Global Middle Class & Local Middle Class \\
\hline Workplace & Work in global fields & Work in local occupations \\
& $\begin{array}{l}\text { Their workplace has a global } \\
\text { environment that involves daily } \\
\text { international contacts and frequent } \\
\text { mobility in the short and long term } \\
\text { Frequent travel abroad }\end{array}$ & $\begin{array}{l}\text { Their workplace involves only } \\
\text { local- Israeli connections }\end{array}$ \\
& $\begin{array}{l}\text { Moved with their families abroad for } \\
\text { extended periods of time (over a year) at } \\
\text { Frequency and duration } \\
\text { of mobility }\end{array}$ & $\begin{array}{l}\text { Occasionally travel for short } \\
\text { vacations abroad }\end{array}$ \\
& Higher education & \\
Education & & Higher education (except 2 fathers) \\
\hline
\end{tabular}


Table 2: Information about the GMC interviewees

\begin{tabular}{|c|c|c|c|c|c|}
\hline Pseudonyms & Occupation & Education & Family unit & Hobbies and leisure activities & Mobility background \\
\hline Patrick & $\begin{array}{l}\text { Project Manager at an } \\
\text { international } \\
\text { pharmaceutical company } \\
\text { Vice President of } \\
\text { Marketing at a start-up } \\
\text { company }\end{array}$ & B.A. & $\begin{array}{l}\text { Married parents } \\
\text { with two } \\
\text { children (two } \\
\text { daughters, ages } \\
6 \text { and } 8 \text { ) }\end{array}$ & $\begin{array}{l}\text { For the children: English interaction } \\
\text { games, Lego, private lessons in English, } \\
\text { dancing and art clubs } \\
\text { As a family: Science and art museums, } \\
\text { try to analyse artwork together }\end{array}$ & $\begin{array}{l}\text { The mother travels aboard for work once a } \\
\text { year and the father once every two weeks. } \\
\text { Moved back to Israel after living with their } \\
\text { family in Boston, USA for a year and a half }\end{array}$ \\
\hline Rachel & $\begin{array}{l}\text { Marcom } \\
\text { Specialist at hi-tech } \\
\text { company in Israel. } \\
\text { Commander of Military } \\
\text { High-Tech } \\
\text { Communication unit }\end{array}$ & M.A. & $\begin{array}{l}\text { Married parents } \\
\text { with three } \\
\text { children (two } \\
\text { daughters ages } \\
17 \text { and } 14 \text { and a } \\
\text { son age } 8 \text { ) }\end{array}$ & $\begin{array}{l}\text { For the children: football, cycling, a } \\
\text { "Dungeons and dragons" fantasy club, } \\
\text { guitar, dance lessons } \\
\text { As a family: Sports, hiking, cycling, } \\
\text { jogging, play "Rummy", theatre, science } \\
\text { museums and art exhibitions }\end{array}$ & $\begin{array}{l}\text { The mother travels aboard for work at least } \\
\text { four times a year and the father once every } \\
\text { two weeks } \\
\text { Moved back to Israel after living with their } \\
\text { family in San Francisco, USA for two years }\end{array}$ \\
\hline Alexander & $\begin{array}{l}\text { A nurse works for a } \\
\text { pharmaceutical company } \\
\text { Involved in the high-tech } \\
\text { sector of the automotive } \\
\text { industry }\end{array}$ & M.A. & $\begin{array}{l}\text { Married parents } \\
\text { with two } \\
\text { children ( } 11 \\
\text { years old boy } \\
\text { and } 7 \text { years old } \\
\text { daughter) }\end{array}$ & $\begin{array}{l}\text { For the children: swimming and dancing } \\
\text { classes, private lessons - skills and } \\
\text { learning strategies. } \\
\text { As a family: hiking in Israel and abroad, } \\
\text { museums }\end{array}$ & $\begin{array}{l}\text { Both parents travel abroad for work every } \\
\text { month or two. Moved back to Israel after } \\
\text { living with their family in Boston, USA for } \\
\text { two years }\end{array}$ \\
\hline Tom & $\begin{array}{l}\text { Customer manager at an } \\
\text { investment company } \\
\text { Involved in financial } \\
\text { investments, capital } \\
\text { markets and real estate }\end{array}$ & B.A. & $\begin{array}{l}\text { A religious } \\
\text { family with four } \\
\text { children (twin } \\
\text { boys age } 18, \text { a } \\
15 \text {-year-old } \\
\text { boy, and a 12- } \\
\text { year-old girl) }\end{array}$ & $\begin{array}{l}\text { For the children: play tennis, guitar } \\
\text { lessons, gym, and horseback riding. } \\
\text { As a family: travel overseas during } \\
\text { summer vacations, family gatherings on } \\
\text { Fridays and Saturdays, and museums }\end{array}$ & $\begin{array}{l}\text { Both parents travel abroad for work every } \\
\text { month or two. Moved back to Israel after } \\
\text { living with their family in Geneva, } \\
\text { Switzerland for ten years, then moved to } \\
\text { Nice, France for a year and then New } \\
\text { Jersey, USA for another year }\end{array}$ \\
\hline Kim & $\begin{array}{l}\text { Chief Financial Officer } \\
\text { at a high tech company } \\
\text { VP of Marketing at an } \\
\text { international high-tech } \\
\text { company }\end{array}$ & M.A. & $\begin{array}{l}\text { Married parents } \\
\text { with three } \\
\text { children (two } \\
\text { boys ages } 13 \\
\text { and } 18 \text {, a girl } \\
\text { age } 6 \text { ) }\end{array}$ & $\begin{array}{l}\text { For the children: volleyball, competitive } \\
\text { gymnastics, and artistic dance. } \\
\text { As a family: restaurants, escape rooms, } \\
\text { trips in Israel and abroad, lectures, } \\
\text { museums, and exhibitions }\end{array}$ & $\begin{array}{l}\text { The mother travels aboard for work every } \\
\text { month or two, and the father once a month }\end{array}$ \\
\hline
\end{tabular}

Table 3: Information about the LMC interviewees 
Miri Yemini, Claire Maxwell \& Ma'ayan Mizrachi (2018): How does mobility shape parental strategies - a case of the Israeli global middle class and their 'immobile' peers in Tel Aviv, Globalisation, Societies and Education, online 1 October 2018

\begin{tabular}{|c|c|c|c|c|c|}
\hline Pseudonyms & Occupation & Education & Family unit & Hobbies and leisure activities & Mobility background \\
\hline $\begin{array}{l}\text { Ella } \\
\text { Adam }\end{array}$ & $\begin{array}{l}\text { Social worker } \\
\text { Sports teacher \& } \\
\text { homeroom teacher at } \\
\text { high school }\end{array}$ & $\begin{array}{l}\text { M.A. } \\
\text { M.A. student }\end{array}$ & $\begin{array}{l}\text { Married parents with two } \\
\text { children (11-year-old boy } \\
\text { and } 8 \text {-year-old girl) }\end{array}$ & $\begin{array}{l}\text { For the children: Judo, art and } \\
\text { hip hop, private lessons in } \\
\text { English and piano } \\
\text { As a family: travel (mainly in } \\
\text { Israel) and family events }\end{array}$ & $\begin{array}{l}\text { About once a year the family goes on a short } \\
\text { vacation abroad }\end{array}$ \\
\hline $\begin{array}{l}\text { Alma } \\
\text { Oscar }\end{array}$ & $\begin{array}{l}\text { Lawyer } \\
\text { Real Estate }\end{array}$ & $\begin{array}{l}\text { B.A. } \\
\text { High school } \\
\text { education }\end{array}$ & $\begin{array}{l}\text { Married parents with three } \\
\text { children (three boys ages } \\
2,3 \text {, and } 8 \text { ) }\end{array}$ & $\begin{array}{l}\text { For the children: sport activities } \\
\text { such as Judo, swimming, } \\
\text { Capoeira and football } \\
\text { As a family: hiking, beach, } \\
\text { movies, and family gatherings }\end{array}$ & $\begin{array}{l}\text { About once a year the family goes on a short } \\
\text { vacation abroad }\end{array}$ \\
\hline Marcus & $\begin{array}{l}\text { Events Designer } \\
\text { Events manager and } \\
\text { businessman }\end{array}$ & $\begin{array}{l}\text { B.A. } \\
\text { B.A. }\end{array}$ & $\begin{array}{l}\text { Married parents with two } \\
\text { children (13-year-old boy } \\
\text { and } 8 \text {-year-old girl) }\end{array}$ & $\begin{array}{l}\text { For the children: artistic dance, } \\
\text { scouts, video games } \\
\text { As a family: vacations in Israel } \\
\text { and abroad, hiking, beach and } \\
\text { picnics }\end{array}$ & $\begin{array}{l}\text { About twice a year the family goes on a short } \\
\text { vacation abroad }\end{array}$ \\
\hline Betty & $\begin{array}{l}\text { Criminal prosecutor } \\
\text { Chairman of the local } \\
\text { radio station }\end{array}$ & $\begin{array}{l}\text { M.A. } \\
\text { M.A. }\end{array}$ & $\begin{array}{l}\text { Married parents with three } \\
\text { children (twin girls age } 7 \\
\text { and a } 10 \text {-year-old boy) }\end{array}$ & $\begin{array}{l}\text { For the children: private lessons } \\
\text { in English, Math, Hebrew, and } \\
\text { chess. Also sports activities such } \\
\text { as gymnastics, hip-hop dancing } \\
\text { and basketball } \\
\text { As a family: hiking in Israel and } \\
\text { abroad, family gatherings and } \\
\text { cycling }\end{array}$ & $\begin{array}{l}\text { About two or three times a year the family goes } \\
\text { on a short vacation abroad }\end{array}$ \\
\hline Marina & 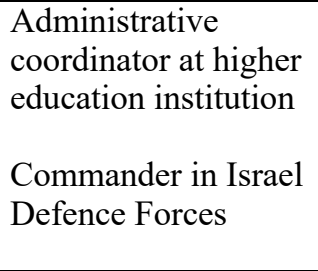 & $\begin{array}{l}\text { High school } \\
\text { education }\end{array}$ & $\begin{array}{l}\text { Married parents with four } \\
\text { children (two boys ages } 13 \\
\text { and } 8 \text {, and twins - a boy } \\
\text { and a girl, age } 6 \text { ) }\end{array}$ & $\begin{array}{l}\text { For the children: "Dungeons and } \\
\text { Dragons" fantasy club, sport } \\
\text { activities such as Capoeira, } \\
\text { gymnastics, and tennis } \\
\text { As a family: table games, family } \\
\text { gatherings, cycling, pool, beach, } \\
\text { restaurants }\end{array}$ & $\begin{array}{l}\text { About once a year the family goes on a short } \\
\text { vacation abroad }\end{array}$ \\
\hline
\end{tabular}


Miri Yemini, Claire Maxwell \& Ma'ayan Mizrachi (2018): How does mobility shape parental strategies - a case of the Israeli global middle class and their 'immobile' peers in Tel Aviv, Globalisation, Societies and Education, online 1 October 2018. 